\title{
LEGAL PRESIDENT'S POSITION IN THE STRUCTURE OF STATE ORGANS (AFTER 1993)
}

\author{
by Sylwester Gardocki
}

The difficult and dramatic birth of the Constitution of the Russian Federation in December 1993 does not mean that it is a statute burdened by numerous faults and chaotic as the situation in which it originated. This is quite a consistent constitutional act looking for a strong presidency model, similar to the Fifth French Republic. It is doubtful, however, that, according to an eminent scholar of Russian law, William E. Butler, at that time "enacting of the truly democratic constitution for the first time in Russian history"1 took a place.

Firstly, a number of amendments to the Constitution of the USSR from 1978 introduced even in the period of perestroika greatly democratized the Constitution ${ }^{2}$ and, secondly, a big advantage over all chief authorities,

1 W.E. Butler, Russian Law, Oxford 1999, p. 273.

2 In the period of perestroika to the old constitution from 1978 there were more than 200 amendments, inter alia, creating the Office of the President and the Constitutional Court, abolishing the Communist Party's leading role and changing the structure of parliament, essentially democratizing the chapter on human and civil rights and changing the principles of the federation in accordance with the contents of the Treaty on Federation from 1992. In December 1992, Congress of Deputies also enacted Article 126 paragraph 6 , which provided that in the event of a termination or suspension of any lawfully established authority, the term of president ruling shall be immediately stopped. This amendment was probably preparing to bring president Boris Yeltsin on trial under 
which were established on the basis of the Constitution of $12^{\text {th }}$ December 1993, to a high degree hampers the implementation of the authorities separation principle which is rightfully regarded as the democratic basis of constitutionalism.

The purpose of this chapter, not being a legal monograph on a constitutional system of the Russian Federation ${ }^{3}$, is to show the complexity of the political-legal status of the president, and the mode of his appointment, core competencies to other state bodies and the major role assigned to him by the Constitution and other constitutional norms, as well as legal limitations of his power. Subsequent chapters will present not only legal aspects but also they will identify primarily social, cultural and political conditions of official actions of Russia's presidents, the true methods used by them - regardless of whether they are consistent with the Constitution - to stay in power and pursue specific policies and approaches. This will allow us to determine the extent to which the roles assigned by law to the presidents are consistent with the actual exercise of their roles and how these roles are performed. It is the only chapter where we have exposed the legal analysis of constitutional and legal institutions and activities of the people on the political scene. The chapter is necessary for further considerations of the hypothesis about the extent and effectiveness of political relations, jurisdiction in contemporary Russia and the model, prefigurative character of the presidential institution for the entire political system of Russia.

Article 126 paragraphs 10 . This shows again how fierce was the struggle between the president and a majority of MPs.

3 Such works have already been written, not only dozens of Russian monographs and constitutional law textbooks. In Polish literature the work of Eugeniusz Zielinski: Contemporary Russia. Political and constitutional system study (Warsaw 1995) is worth mentioning. Russian Federation Parliament (Warsaw 2002) and the Constitutional system of the Russian Federation (Warsaw 2005). 


\section{THE PRESIDENT AS HEAD OF STATE AND HEAD OF THE EXECUTIVE POWER}

The Constitution did not repeal the law on president from 1991, specifying his role in the structure of prime organs of the state. Under the Act of 1991, the president is the "most important person in the state and the head of executive power" (Article 121 of the revised Constitution from 1978)4, while the new constitution from 1993 describes him as "Head of State" (Article 80), which - with reference to the universal tradition represents the Russian Federation in the country and in international relationships. This ambiguity is settled in such a way that the President is located above the other state authorities, but most of his duties and powers belong to the sphere of executive power. So the role of the president should not be reduced merely to this area (as did the previous law), his role must be somewhat dual. As Lew Okunkov wrote in 1995, the then director of the Institute of Legislation and Comparative Jurisprudence of the Government of the Russian Federation:

- "The fact of non-inclusion of the president in any of the three branches of power (Article 10) does not mean the fact that the presidential status is beyond being determined" 5 , it would be worse if the president was identified as the fourth power;

- "The institution of president was created somewhat above the branches of power with a possibility of putting pressure on him what is not always associated with the principle of independence"6, and "for normal operation and cooperation of the branches of power the president should remain in the organic ties with these structures of public authority, not swaggering";

4 President of the RSFSR Act 24 April 1991, No. 1098-1, cf. "Vedomosti Sjezda Narodnych Dieputatow Rossiyskoy Fiedieracji and Wierchownogo Soviets Rossiyskoy Fiedieraciji" 1991, No. 17, item. 512 in further refrences will refer to this source text.

5 L.A. Okunkov, Priezidient Rossiyskoy Fiedieraciji: konstitucija and politiczeskaja praktika, Moscow 1996, p. 5.

6 Ibidem, p. 5.

7 Ibidem, p. 7. 
- "Most of the powers of the president refers to the sphere of executive power at the federal level" 8 ; in the same time

- "We cannot not forget that the only level (vertical) of the executive authority in the Russian Federation is headed (wozglawlajetsja) by the federal government".

It occurs that Russian constitutional law has not resolved clearly and unequivocally the major structural problem - the dualism of the vertical subordination of executive power ${ }^{10}$. No wonder that both President Boris Yeltsin and President Vladimir Putin have continually tried to subjugate the entire executive power, which could put the Prime Minister (e.g. Prime Minister Viktor Chernomyrdin and Yevgeny Primakov in the second term of President B. Yeltsin) in a difficult situation, invoking the constitution and the reluctant "role of a whipping boy" protecting this president before the parliament and critical public opinion. This will be detailed in the next chapter, devoted to the president's relationship with the federal government. It is enough to mention here the fact that the problem resulted from the Russian legislation and it hampered harmonious cooperation of the state bodies.

Also in the Soviet political system, there were dual of roles and positions at the highest level, which were a consequence of the principles of the communist party's leadership role in the state ${ }^{11}$. This duality is often depicted as a doctrinal principle, according to which "directs the party and the government governs". This was the basis for the duplication of roles, unclear division of powers and the blurring the boundaries of institutional responsibility and limiting the effectiveness of the excessive

8 Ibidem, p. 7.

9 Ibidem, p. 9.

10 Contrary to what is often thought, this is not president Putin first started talking and working towards a wertikali ispolnitielnoj wlasti, but advisers to President Yeltsin and he himself. Yeltsin did not succeed, and President Putin stopped the process of the Russian Federation disintegration, the brutal war in Chechnya was part of this action, but you should not lose sight of the institutional use of the regional laws reconciliation with federal laws or order restoration in the enforcement of taxes for the federation.

11 Joseph Stalin in the later period of his ruling solved the problem of duality in this way, that from 1941 until his own death in 1953 he was the head of the party and head of government. 
number of institutions. Instead of the old dualism of institutional roles and duplication of the party apparatus and the state apparatus, under the Russian constitution of 1993 there was a problem with duality of subordination of the executive power: to the president de facto and to the prime minister de jure. And, of course, the dualism of two administrative apparatus - presidential and the one that is subordinate to the prime minister, which compete with each other, and the presidential apparatus is the controller of the governmental one, as it was in the past when KPZR (Communist Party of the Soviet Union ) was the controller of the state administration.

Such dualistic institutional models rarely function well and peacefully. Political institutions are formed, however, in order to institutionalize a conflict between people performing important roles in the process of governance and create procedures to resolve them.

In both cases - the USSR and the Russian Federation - in reality the dualism found in the institutional model was reduced to the supremacy of monism and monocentric over the executive power, to the predominance of one entity represented in the past by the head of the party, now it is the president of the state. President de jure is the only head of state, but de facto (and partially de jure) he is also the head of the executive power and an important participant in the creation of law, occupying this role he is often on a collision course with both houses of parliament. It is institutionally placed in the two conflicting areas of state power: in the executive area he is to exercise this power directly and indirectly, as if it was through the hands of the Prime Minister and ministers, which leads to the duality of command, while in the area of legislative power the president is equipped in so numerous and significant powers that he often falls into conflicts with parliament - especially when the majority of parliament does not share the views of the president and his close circle of associates.

In the constitution from 1993 there are also cases of omission of the vice-president office, introduced by the amendments to the Constitution of the RSFSR in 1991. The office was ruled by general Aleksandr Ruckoj, who was initially an ally of Yeltsin, then a rival and one of the leaders of the parliamentary majority, with which Yeltsin came into sharp conflict 
combined with the use of armed forces in October 1993. It turned out that in terms of the Russian institutional model providing two people at the top encourages conflict riddled leadership and can threaten political stability, and even the existence of the state.

In connection with the issue of duality of the leadership of many experts on Russia and on the Soviet system say that these were the leaders prone to ruthless competition, to fight without compromise and mutual concessions, to confront the "life and death" in which the winner takes all, led to the dissolution of the USSR, disintegration of the empire against the wishes and opinions of the vast majority of citizens of the USSR ${ }^{12}$. The conflict between Boris Yeltsin with Mikhail Gorbachev was about power over the Soviet Union, not just the Russian Federation. We can rightfully assume that if Yeltsin had managed to move Mikhail Gorbachev from power and he became the president of the entire Soviet Union, then he might have never declared sovereignty of Russia and would not have led to the end of the already advanced disintegration of the Soviet Union. Boris Yeltsin had many conflicts with rivals who initially did not want his presidency, and later tried to take it away from him, or at least weaken its position or to block the economic reforms initiated by him. The shape of new institutions (such as a strong presidency and a weak parliament, or by selecting a model of half presidential following the French model, not the parliamentary model) was often determined by the reasons of personal and tactical requirements of the leaders struggling for authority, not long-range strategic thinking ${ }^{13}$.

12 Data from studies of social consciousness show that both in the period 1990-1991, as well as many years after the dissolution of the Soviet Union, most Russians, as well as non-Russian Soviet citizens wished to continue the existence of a federation, even if it was to be reduced by some countries (e.g. Baltic Republics and some countries Caucasian). This was interestingly presented by S.F. Cohen, Was the Soviet System Reformable?, "Slavic Review" 2004, No. 3.

13 Lilia Szewcowa writes aptly about tactical and personal premises of the creation of new institutions of the Russian state after the collapse of the Soviet Union and the tendency to monopolize power by the people and institutions, not willing to share the resources. L. Shevtsov, Parliament and the Political Crisis in Russia, 1991-1993, [in:] J.H. Hahn, Democratization in Russia: The Development of Legislative Institutions, New York 1996, p. 38; I. Klyamkin, L. Shevtsova, This Omnipotent and Impotent Government: The 
Debate in Russia suggests that politicians and constitutionalists are aware of the opaque institutional dualism, and its potential contradiction with the principle of separation of powers presented in the Constitution of the Russian Federation ${ }^{14}$. Article 10 of the Constitution provides that "power in the Russian Federation is exercised on the basis of its division into legislative, executive and judicial. Legislative, executive and judiciary bodies are independent". Independence in terms of institutions should mean a particular way of the division of powers and duties - counteracting violations of spheres of competence of another authority and to ensure that such cases do not remain unpunished. The different types of authority should be independent from each other, although not necessarily should have equal decision-making power and the equivalent position in the hierarchy of power ${ }^{15}$.

The Russian constitution does not talk about sharing and cooperation of the authorities, but only about the division ${ }^{16}$. On the other hand, the

Evolution of the Political System in Post-Communist Russia, Moscow 1999, pp. 10 and further.

14 See E.W. Pushkin, Status priezidienta in usłowijach włastnych protiwowiesow, Moscow 2001; many voices in Rossijskij parlamientarizm wX wiekie: matieriały krugłogo stoła, Moscow 2000; L.A. Okunkov, Pierspiektiwy raspriedielenija połnomoczij mieżdu Priezidientom, Prawitielstwom and Fiedieralnym Sobranijem, "Zakonodatielstwo" 2000, No. 9; E.C. Czirkin, Priezidientskaja Wlast,', "Gosudarstvo i Prawo" 1997, No. 5; A. Mieduszewskij, Rossiyskaya modiel konstitucijonnych prieobrazowanij in srawnitielnoj pierspiektiwie, "Konstitucijonnoje Prawo: Wostocznojewropiejskoje Obozrienije" (hereafter cited as KPWO) 2003, No. 2, ditto, Bonapartistskaja modiel własti dlia Rossiji?, KPWO 2001, No. 1.

15 Russian literature has long been embroiled in a fundamental dispute - whether the Constitution of the Russian clearly and accurately expresses the principle of separation of powers, or rather, it merely declares, because de jure and de facto in fact there is expressed a principle of sovereignty of the president, because of structural weakness of the parliament and the aforementioned duality subordination of the executive. The authors of the critical attitude towards the style of governance and institutional foundations generally defend the second view, sometimes calling for amendment of the constitution from 1993. Detailed analysis of the legal arguments of various participants in this discussion goes beyond the set goal of this work. It is worth noticing that long-term dispute demonstrates signifies a great tie to the importance and the quality of the legal framework.

16 Many modern constitutions, including the Polish constitution, the second element significantly underlines and creates the institutional tools necessary for such cooperation 
Russian Constitution clearly implies the need for harmonization of the authorities and as a result it entrusted to the President of the Russian Federation (in the art. 85) the use of conciliation procedures (sogtasitielnyje prociedury). But might the president really be an arbitrator between different levels and types of power?

Such a task of an arbitrator or a mediator is entrusted with the presidents of many countries, because this is the traditional role of the head of a state in a democratic system, even if it is not a republic, but a constitutional monarchy. That is not in the Russian Federation, despite the extensiveness of the sharp conflict between the government and, the president before the enactment of the constitution, and so the creators of the constitution should presume that in future conflicts of interests may be big (especially against the disintegration of the empire and external procedure, if you want to change the economic system and many of the principles of state policy). The arbitration procedure in article 85 does not apply, however, to the coordination of the policy between the different types or branches of government at the federal level. What the text says abut sogłasitielnych prociedurach in the constitution indicates that the intention of the legislature was only to ensure a compliance of the federal government with the authorities throughout the Russian Federation. The mitigating procedure in article 85 does not concern reconciliations between politics between different types of branches or federal authorities, which typically occur between the government and a bicameral parliament. The Constitution governs only the president's role in mitigating the differences between the various levels of authority (ie, between federal authorities and authorities of the federal government) and the differences between the various bodies of the federal government. Therefore, these procedures are simply the result of the principle of federalism in the constitution adopted, and have nothing to do with the principle of separation and all kinds of authorities at the federal level. As these procedures are applied and what were the presidents of other methods of operation in ensuring the unity

and the mutual control so that it would be difficult for one body to impose anything onto another. 
of the state, this will be discussed in Chapter VI on the relationship: the president and the authorities of the republics and regions.

The purpose of the institutional mechanisms of building compromises at the federal level should partially restore unity or cohesion of official actions of the state, notwithstanding the principle of the separation of powers and their mutual autonomy. Accordingly, by tacit assumption, there should be recognised the necessity of cooperation of the authorities, with maintaining their mutual independence, so that they would be able to, and would have to, control one another, which would prevent them from falling into the trap of absolutism, authoritarianism or excessive arbitrariness. However, this is not the case, because the Russian constitution provides for such an advantage over the other principal organs that it does not care for the cooperation of federal authorities based on the principle of compromise. Perhaps this is why in the constitution there is no mention of the collaboration of the different branches of federal authorities - its creators furnished the president with such strong constitutional measures, because they deemed it needless to anticipate the reaching of agreement, the building of compromises, which are the basis of democracy at state level and the smallest community.

In the present constitution, just as in the manner of its introduction, there is consistently implemented the precept of extraordinary power of the president relative to the other organs of federal authorities. The constitution was not created as a result of a compromise and does not stipulate that compromises are necessarily needed ${ }^{17}$. The intellectual foundation of the Russian constitution seems to be the conviction, established in the political traditions of tsarist absolutism and single-party dictatorship, that politics imposes the will of a single entity, the supreme leader, on all others, regardless of whether the principle of the separation of powers has been included in the constitution. It is not compromise, but non-compromising of the acts of the supreme will, their non-alternativeness and peculiar ruthlessness that is the ulterior premise here, as if there were no place for diversity of opinion, so natural for people, and the competition

17 A similar view is expressed by R. Sakva, Institut priezidientstva: libieralni ili nyeopatyernalystsky polityczesky ryezhym, KPWO 2003, No. 4. 
of opinions and interests of various social groups inherent in a multipartisan system. It was not assumed that interests are often many, that there is no indivisible interest and decisions that cannot result from the rule that the winner of a presidential election is absolutely correct and his view is simply the raison d'état.

Describing the presidential draft of the constitution, one of its authors, Sergey Alekseev stated that "throughout the entire draft runs the idea of presidential beginning" (pryeziedientskoye natshawo is in Russian something more than beginning, it is also foundation, the most fundamental source $)^{18}$. This is a reliable characteristic of the constitution, though it was uttered with apologetic, not critical intent.

After passing the constitution and the experiences with the style of $\mathrm{B}$. Yeltsin's presidency, constitutional debate was going on with the aim to introduce amendments demarcating the president's authority, or at least narrowing it down, so that the legal limits of his power would be clear. In connection with fears of presidential authoritarianism, there was postulated the preparation of a new law on the president and the replacement of 11 articles passed in 1991 with a detailed normative act which would be able subject to specific regulation of the methods of carrying out any of the authority by the president - both in his relations with the government and parliament ${ }^{19}$.

The arguments of critics of the Russian presidential system are intended to effect an increase of the role and responsibility of parliament for the state of law and the government's policy, convinced that a weak parliament is the lair of irresponsibility and populism of party politicians, who clumsily try to be the conscience of the nation, but devoid of actual influence

18 Konstitucyionnoye sovieshtshanye. Stienogramy. Matieriawy. Dokumienta, v. I, Moscow 1995, p. 7.

19 For instance, A. Cypko, Priezidientskye vybory v Rossyi nado otmienit', "Niezavisimaya Gazieta”, 20.02.1995. In the later period, this author supported President Putin's policy and did not postulate any changes to the constitution. Far-reaching draft changes were also postulated by a team of experts in: Izmienienye konstitucyi? Projekt Stratiegya dlia Rossyi, Soviet po Vnieshniey i Oboronnoy Politikie, "Niezawisimaja Gazieta", 6.11.1998: O konstitucyionnoy rieformie, Projekt Stratiegya dlia Rossyi, Soviet po Vnieshniey i Oboronnoy Politikie, 2000, www.svop.ru/live/materials.asp?m_id=6747\&r_id=6836. 
on the decisions of the executive, they do not feel responsible for the condition of the country. In other words, too powerful a presidency rebounds to the parliament's being divested of significance and degenerating, and the party system losing its representativeness. Irresponsibility and frequent corruption of parliamentary politicians make the voters trust nobody and take an attitude of cynical passivity, which may be the rational response to the actions of highly personalised authorities and a reaction to their experiences in contacts with the government apparatus. Critics believe, in general, that a too powerful presidency is the main cause behind the weakness of the political parties and the parliament, that by this it impedes the development of a democratic political culture and delays the consolidation of democracy in Russia ${ }^{20}$.

Since 1994, these have been the main trends in criticism of the constitution and in particular of political practice which this constitution is to legitimise. Criticism has not brought the desired results thus far. At the same time, during B. Yeltsin's capricious and corrupt presidency, the critics' prognosis which predicted that the president would be too powerful and would destroy the germs of a democratic political culture, did not come to pass. Yeltsin did not become a dictator: despite substantial constitutional authorisations, during his tenure, federal authorities became much weaker, internal disintegration of the Russian Federation progressed rapidly and the former republics of the Soviet Union continued to move away from Russia. In a word, the strong institutional framework did not inhibit the overgrowth of freedom into a state approximating anarchy and lawlessness. Disorder reproduced spontaneously, bureaucratic anarchy on the federal level unfolded and secessionist drives in many of the federation's entities intensified.

For this reason, what was expected of the new president was mainly order and predictability, and also strength which B. Yeltsin, along with his court of family members and satellites, did not possess. Only during V. Putin's second term did we see a more powerful manifestation of the

20 These problems will be considered after analysing the actions of the president towards the parliament and the parties. It suffices to indicate here that the constitution is an object at issue in Russia, it has many critics, but it could not be amended. Therefore, despite its flaws, it is stable. 
increasing tendency of authoritarian characteristics in the style of his presidency, although many observers maintain that Yeltsin's authoritarian style was obvious, despite the weakness of his personality, habits and illnesses. The fact that Yeltsin's personal weakness slowed down the revelation of all the consequences of the president's institutional power, does not prove that critics of the constitution were not right and the constitution does not contain germs of authoritarianism. It does prove, however, that the personal factor in Russian political culture continues to have a greater impact than institutional constructions. This may explain why the citizens of Russia are more disposed to trust certain people than impersonal political and legal institutions.

The struggle between the president and parliament would continue: the president won before the passage of the constitution and directly after its adoption (which can be seen in the text of the constitution), then became weaker and before the 1996 elections his prestige and authority were rated so low that it seemed that parliament would have the upper hand. But that did not happen and again the efforts of the proponents of balanced relations between the president (and his government) and parliament were dominated by the president, who was increasingly turning into a hostage of the financial oligarchy and a prisoner of his own flaws and weaknesses. In the later period, V. Putin's traits had such an impact on the situation that with insubstantial changes in the institutional sphere he quickly rebuilt the power of federal authorities, enhanced his personal popularity and in his second term began to use methods revealing the potential for authoritarianism existing in the constitutional premises of the regime of the Russian Federation. This time, the personal factor prevailed again: V. Putin's strong personality activated those institutional potentialities which B. Yeltsin was unable to fully utilise, due to his personal weaknesses. He often behaved unpredictably and despotically, but was inconsistent in implementing his will and often changed his mind under the influence of secondary factors. Just as Yeltsin's traits predetermined the institutions' not operating with transparent authoritativeness, similarly, in turn, V. Putin's inner discipline and the ability to act consistently educed from these institutions their dormant authoritarian potential. 
The president of Russia is both the head of state and the executive, and a key legislative organ; in addition, he has numerous powers enabling him to act as an arbitrator in conflicts between federal organs and organs of the entities of the Russian Federation. The practice of the functioning of both hitherto Russian presidents has shown that the constitutional complexity of the president's role and his multifaceted status are not coincidental. The president has a great many roles - so many that it is not clear whether the principle of the separation of powers really is the fundament of government in the Russian Federation.

Estimations of Russian constitutionalists usually point to these ambiguities $^{21}$. Analyses of Polish authors also touch upon the extraordinary status of the president of Russia. Eugeniusz Zieliński quite rightly claims that "to put it in the most general terms, the president of the Russian Federation focuses state power in the area of government and the legislative. Formally, the office of the president is among the organs of the executive, but the powers bestowed upon him greatly exceed this authority"22. Further still goes the assessment of Andrzej Czajkowski, who upon quoting the opinion of some Russian constitutionalists stating that it is difficult to subsume the president into any branch of power, himself notes that "the constitution has also situated the president above the other organs of power" 23 .

In current discussions in the West, there are mainly considered reasons for which normative semi-presidentialism has transformed into de facto super-presidentialism ${ }^{24}$. During President Putin's second term, it became quite clear that it was super-presidentialism and rarely there are seen

21 Cf. G.V. Diegtiev, Konstituciionno-pravovoy status Priezidienta Rossiiskoy Fiedieracyi i SShA: Sravnitielno-pravovoy analiz, Moscow 2003; V.I. Kaynov, Konstitucyionnopravovoy status Priezidienta Rossii: tieorya i praktika, Saint Petersburg 1999; J. Dmitryev, Priezidientstvo $v$ Rossti kak rielikt monarhitsheskoy vuasti, "Pravo i Zhizn" 1999, No. 20; idem, Pravovoy status Priezidienta Rossyiskoy Fiedieracii, Moscow 1997; V.I. Suvorov, Guava rossyiskogo gosudarstwa, Moscow 2000.

22 E. Zielinski, System konstytucyjny Federacji Rosyjskiej, Warsaw 2005, p. 56.

23 A. Czajowski, Ustrój konstytucyjny, [in:] Russia, eds. B.J. Albin, W. Baluk, Wrocław 2003, p. 53.

24 S. Holmes, Sviertshpriezidientstvo i yego probliemi, KPWO 1993, No. 4 and 1994, No. 1; S. Fish in numerous studies on present-day Russia. 
attempts at defending other views. At present, the argument is not concerned with whether this is an unusually powerful presidency, but why this is so; is it a function of the content of the constitution itself, or rather of the cultural heritage of Russia and the cultural circumstances of styles of tenures of both consecutive presidents. The differences in the assessments are also related to the question, whether Russia is still some form of unconsolidated democracy, or something intermediate between a dictatorship and a democracy, or even an authoritarian system. An attempt at answering these questions will be made in the final part of this book. They can be answered reasonably only when it has been determined what presidential roles result from the constitution and what are the answer to practical dilemmas of governance and reforming Russia.

Further analysis will show how the interrelation of personal and institutional factors from the perspective of the cultural reality of post-communist societies contributed to the intermingling of new democratic procedures and authoritarian traditions. The institutionalisation of personal ambitions and opinions is never fully possible, in any society. However, in the Russian political culture, it is particularly difficult to bring about harmonious cooperation of the personal and political aspects of politics ${ }^{25}$.

Theoreticians of democracy, in particular authors dealing with consolidation of new democracies, underscore the significance of proper selection of the model of institutionalisation of state authorities, the role of stable rules of governance for democratic changes in societies with little experience in the use of constitutions, and also other legal rules restricting personal arbitrariness and manifestations of personalisation of authorities ${ }^{26}$.

25 Por. A. Sulek, J. Styk (eds.), Ludzie i instytucje, Lublin 1995. Of particular usefulness is the article by Adam Przeworski on presidentialism and parliamentarism, on their persistence and efficient government.

26 J. Elster, C. Offe, U. Preuss, Institutional Design in Post-Communist Societies, Cambrigde 1988. A special place in the literature on the causes of the fall of the communist system belongs to the book by V. Bunce, Subversive Institutions. The Design and Destruction of Socialism and the State, Cambridge 1999 and the discussion which it triggered 
The harmonious unification of the government of certain people with the government of general rules is the foundation of consolidated democracy $^{27}$. People change as a result of elections and other procedures, general rules of the formation of power structures and the execution of authority are much firmer, which allows for the combination of stability and change into a system capable of life and development. With the relative stability of the rules of the game, decisions become more predictable, though due to the pluralism of interests they are always uncertain. Whether successful consolidation of the Russian democracy depends to a significant degree on the roles played by presidents, on whether in their actions they will be able to, want to and know how to curb tendencies to the personalisation

about the methodological values of neoinstitutionalism in political sciences and research on societies which have experienced the communist institutional system.

27 In his general definition of democracy, Adam Przeworski accurately points to the fact that the foundation of democracy consists in the rules of rules, rather than people, and that rules are stable, whereas people change and are volatile by nature in their preferences and behaviours. The reliability of rules and the uncertainty of results, that is decisions taken, are the basis of democracy. A. Przeworski, States and Markets: A Primer in Political Economy, New York 2003 and his other, earlier works. The stabilising effect of rules, or institutionalisation, is universally recognised in economic and political theory, nevertheless the drive towards the governance of impersonal rules alone (e.g., the government of legal rules), and not people, which is evident in Przeworski's standpoint and many other proponents of the rational choice theory, is a too advanced idealisation. In no democracy, even the most stable and consolidated with respect to its culture, has it been possible to eliminate the government of people and replace it with the government of law or other general and abstract rules. And it is very doubtful, whether such fully impersonal governance of rules, paradigms or algorithms is possible in the conceivable future, and if it were possible, whether it would be something good for human development. Indicating the need to institutionalise political relations is about pointing out the risk of too radical personalisation of authority, especially authority at the highest level. It is not only in Russia that this has not been solved satisfactorily and there are possible different variants of institutionalisation. In assessing which or what variant of institutionalisation is the most conducive for stable democracy, of significance are the characteristics of the political culture of a society, in particular of the culture of its political elites. Institutions as systems of rules and principles are part of culture, and not only a work of some elite of designers freely shaping the institutional framework of social life. History, the heritage of the past, matters even when we are dealing with the reception of an institutional model from the outside, as in the case of Russian presidency. 
of power and create an environment for the progress of the institutionalisation of political relations. This is conditional on the development of presidency itself, rather than other organs of the Russian state.

The institutional model of the 1993 constitution permits both advances of institutionalisation, as well as the continuation of the tradition of personalisation of the highest authority. This constitutional model is a formal democracy (and here one could partially agree with the quoted opinion of William E. Butler), in which, however, an authoritarian element exists, and whether it will be more or less evident, does not depend on the content of the very constitutional norms, but on many other factors, including personal traits and the style of work of politicians who will become presidents of the Russian Federation in the future. Even super-presidentialism can be democratic, if other conditions are met and semi-presidentialism can have authoritative characteristics ${ }^{28}$.

\section{THE RULES FOR ELECTING THE PRESIDENT OF THE RUSSIAN FEDERATION}

The precepts of electing the president are contained not only in the constitution, but also in other federal statutes. Despite the lack of amendments to the constitution, the rules for parliamentary elections have been changed as many as six times and now a fourth federal act specifies the foundations of electing the presedent ${ }^{29}$. This frequency of altering the rules

28 The ambiguity of any form of presidentialism is taught by the brilliant analyses of the shortcomings of such a model of authority, conducted for many years by Juan Linz. J.J. Linz, B. Valanzuela (eds.), The Failure of Presidential Democracy, London-Baltimore 1994.

29 Cf. the opinion of A. Czajowski, op.cit., pp. 39-42. The first act on presidential elections, back in the days of the Russian Soviet Federative Socialist Republic, from 24 April 1991, totalled only 17 rather general articles and was of a temporary character; its validity expired with the coming into force of the RF Constitution of 12 December 1993. The second act on RF presidential elections of 17 May 1995 was an expanded one and consisted of 62 more detailed articles. The 'firmness' of this legal regulation was increasing, which was aptly noted by L.A. Okunkov, Priezidient Rossyiskoy Fiedieracii: konstituciya i polititsheskaya praktika, op.cit., p. 23. 
indicates a continued search for a better variant of the institutionalisation of political instruments within the Russian state. The rules are not stable and are rather the result of the mutability of power structures, than a factor stabilising those structures. New election legislation is passed before every elections and it cannot be predicted what the terms of vying for support will be during the next election. Two consecutive presidential elections without modifying the election law could be deemed an indication of progressing consolidation of democracy, at least from the formal point of view.

Changes in federal statutes on presidential elections did not arise from the president's status being refashioned; they were a function of modifications in the legislation regulating the status of political parties, an effect of drives to strengthen the role of the parties in elections and in governing the country. They were related in particular to primarily not only the parties, but also numerous other social entities being able to put forward their candidates in parliamentary elections. Indirectly, this undermined the legal position of the parties and obstructed their consolidation in terms of the programme, as well as organisation and finances, because the traditional duties of the parties could also be carried out by other organisations, or even casual and formed ad hoc social unions. Although generally the direction of the changes in the election law of Russia could be seen as positive, conducive to the institutionalisation of the parties, but frequent that conjectures are the actual intention is primarily the desire to reinforce another 'power party'.

In the presidential elections of 1991, 1996 and 2000, and in the elections to the State Duma in 1993, 1995 and 1999, to putting forward candidates were entitled groups of voters, social organisations and election blocs. In 1995 , there was added the possibility of proposing oneself as a candidate to the Duma by any citizen of 21 years of age, eligible to vote and stand for election. It was believed that the parties were still too weakly established in the public life, so as to have the exclusive right to put forward candidates and conduct election campaigns. Only the passage of the federal act of 12 June 2002 on the fundamental guarantees of voting rights and the right to participate in the referendum of the citizens of the Russian Federation (a third one with the same title and differing content) conferred 
to political parties the unique role of organisations specialised in contending for seats in the structure of state administration, assigned through elections. Only from this moment onward parties have had the exclusive right to put forward candidates. This regulation is a superordinate act in relation to election acts amended at a quicker pace. Accordingly, the Russian constitutional legislation has four levels of normative acts pertaining to electing the president: the constitution, the already mentioned federal act on the fundamental guarantees, federal election acts and certain other statutes (e.g., the establishment of election committees is regulated by the act on social organisations) $)^{30}$. Among the constitutional tenets of the political system ${ }^{31}$, the principle of a democratic state of law is of direct significance for any elections, including the elections of the president of the Russian Federation. Voting rights are commonly seen as the fundamental manifestation of realisation of this particular principle of the political system. The Russian doctrine distinguishes three aspects of sovereignty, with regard to: the people, the nation and the state, which is a result of the multinational and federal character of the Russian state.

The president is elected by the citizens of the Russian Federation on the basis of their voting right, which is general, equal and direct, and also in a secret vote. The participation of the citizens in elections is voluntary and nobody may be liable to any legal or moral sanctions for denying participation (Art.1 of the RF Presidential Election Act). This norm is of particular significance for the citizens of the Russian Federation, who for many years were forced to take part in fictitious elections of the Soviet type, in which there was no choice - the political programme was the only and correct one, passed by the Central Committee of the CPSU, the only party existing under Soviet law and ruling by the power of the doctrine of the leading role of the party.

30 The last election act is Fiedieralny Zakon ot 10 yanwariya 2003 goda o wyborah Priezidienta Rossiyskoy Fiedieraciy, Sobranije Zakonodatielstwa Rossijskoj Fiedieraciji 2003, No. 19.

31 About their content have written, apart from Russian lawyers: E. Zieliński, System konstytucyjny Federacji Rosyjskiej, op.cit., pp. 18-23; A. Czajowski, op.cit., p. 37-51; A. Stelmach, Zmiana i stabilność w systemie politycznym współczesnej Rosji, Poznań 2003, pp. 68-89. 
The candidate must gain an absolute majority of the votes of all eligible citizens, with attendance not lower than $50 \%$ of eligible voters. If no candidate gains such support in the second round, the two strongest candidates contend in the second round and in order to win, it is required to gain a number of votes greater than that obtained by the rival and those who have voted against both candidates. It is therefore not possible to win with a minimum amount of votes, if votes cast against the two are in a way counted as being in favour of the weaker of the candidates. The Russian election law has introduced an interesting institution - the right to cast a vote against all candidates with such a legal consequence, that the winner should have more votes than the rival and against both candidates. Typically, there have been slightly more rejecting votes in the first round than in the second, but their number is usually a few per cent of all votes cast. This institution was abrogated in 2006.

The introduction of direct and general elections of the highest state organ is a fundamental change in the history of the Russian political systems. Formerly, it was either court intrigues with the monarchic principle of succession to the throne, or the struggle within the communist party, hidden from the public, that decided who would attain the position of the supreme leader. Oftentimes an assassination in the ruling family or among the communist leaders was a necessary rung to climb to the highest position. The principle of succession of power and the basis of its legitimisation have been radically changed, though a singular arrangement should be remembered which President B. Yeltsin and his family made with V. Putin. There was an element of court intrigue and a cabinet cabal to it, but ultimately V. Putin could become the president only following successful elections. Shortly after the elections, V. Putin issued a decree which guaranteed a privilege of immunity to the former president and many people close to him, which protected their interests and silenced the fears of other than political responsibility.

This experience revealed not only the extent of depravation at the summit of power, but also the dominance of exceptions to rules designed ad personam over general principles of law and justice. This shadow over the first succession of presidential power in Russia is no less important than the manner in which B. Yeltsin forced the passage of the constitution in 
December 1993. Both situations demonstrated how uncertain and unsound the institutionalisation of power is at the highest level in Russia.

The electoral road to power invests the president with democratic and the highest in all of the political system legitimisation to govern, for no other person in the country is appointed to office in this manner. The president is elected by a majority of citizens (and not by the majority of a committee or council) and holds a strong title to power; however, as opposed to tsars or secretaries-general of the communist party, he is not given such power for life or without a specific time limit for its execution. According to the constitution, the president is elected for a 4-year term, he can be in office only for two terms in a row and have no legal possibility of extending the period of holding the office by the same person, even if he were to have extraordinary social esteem allowing him to count on a reelection ${ }^{32}$. The fact that speculations about a possible amendment permitting a third tenure in a row that went on in the media for a long time and was an expression of both the very high position of V. Putin in the rankings of social trust, as well as the presumptions of many analysts that the constitutional institutionalisation of the rules of presidency was still so superficial that such a possibility could not have been completely excluded.

Since the president has a very broad authority and the strongest democratic legitimisation, the conditions which a candidate for this office has to meet are essential. They are nothing unusual in comparison to the requirements of other contemporary constitutions in terms of the right to stand for election. The candidate must be a citizen of the Russian Federation, have a right to vote, be a permanent resident in the Russian territory for not less than 10 years and be not less than 35 years of age. There is no upper limit for the candidate's age, nor are there specified any requirements in regard to experience or education. It is worth noting that there is no

32 In the period 1991-1993, until the passage of the constitution of 12 December 1993, the presidential term was longer and lasted five years, but just as today, only two terms in a row were allowed by the first act on the president from 1991. The rule of a maximum of two consecutive terms is commonly adopted in contemporary democracies, but in some post-Soviet republics in Central Asia, regulations on lifelong presidencies have been passed. 
constraint on running for the office of people of nationalities other than Russian, nor for those born outside the borders of the Russian Federation $^{33}$. This is a clear consequence of the multinational composition of the society of the Russian Federation - the existence of any such restrictions would discriminate against more than 100 minority ethnic groups whose representatives are the citizens of this country.

Of greater significance was the issue of putting forward candidates for the president's office: who can submit their candidature and how much support they should have, in order to be accepted by the election commis$\operatorname{sion}^{34}$. Until 2003, the right to propose candidates was held by social organisations, political movements and electoral blocs which had to gather at least 1 million signatures of citizens supporting a candidature, with the reservation that within a single entity of the RF not more than $7 \%$ of the total required amount of signatures could be gathered ${ }^{35}$.

In the elections of 2004, when V. Putin ran for the second time, new election rules were already in place. The most important change was that at now only political parties could submit their candidatures. The requirements regarding support for their candidates are related to the statuses of parties submitting candidatures. If a party proposing a candidate in the last elections for the State Duma gathered at least $5 \%$ of the votes, it does not have to collect signatures in support of that candidature. Whereas weaker, less popular parties need to collect as many as 2 million signatures, which undoubtedly poses a significant hindrance to submitting candidatures, but it was the intention of legislators to delimit the number of candidates with doubtful social prestige and unclear political

33 For earlier election regulations, cf. A.E. Postnikov, Izbiratielnoye pravo Rossiy, Moscow 1996; W.E. Butler, Russian Law, Oxford 1999, pp. 282-283.

34 Cf. J.P. Willerton Jr., Presidential Power, [in:] Developments in Russian Politics, eds. S. White, A. Pravda, Z. Gitelman, London 1997.

35 In this manner were submitted the candidatures of B. Yeltsin in 1996 and V. Putin in 2000, and of other candidates, who were not elected at that time. The procedure of signature collection, registration of groups initiated by the Ministry of Justice and other procedural issues under the preceding presidential elections act have been discussed by A. Stelmach, Zmiana i stabilność w systemie politycznym współczesnej Rosji, Poznań 2003, pp. 223-224. 
support ${ }^{36}$. It is still possible to submit one's own candidature. In order to do this, there has to be organised at least one citizens' assembly, at which at least 500 voters should express their support, and additionally 2 million signatures need to be collected. It stands to reason that under such conditions self-running candidates may be very few and perhaps this was the legislative body's intent.

Just as before, elections are announced and their dates set by the Federation Council, which announces its decisions at least four months before the election day. The dates in the election calendar are determined by the constitution and the Federation Council may not set them arbitrarily. Once set and announced, the election day may not be changed by the Federation Council with a later decision. The election commissions of the candidates may be formed only following the announcement of the election date, though in practice main candidates begin informal preparations much earlier. If, for some reason, the Federation Council were to fail to fulfil its constitutional duties, the decision on conducting a presidential election within the constitutional time limit should be made by the Central Electoral Committee of the Russian Federation. All costs of an election related to its preparation and conduct by the state apparatus are borne by the state treasury, with the exception of expenses of election commissions supporting their respective candidates.

The preparation and conduct of an election of the president of the Russian Federation is done by the Central Electoral Committee of the RF, election commissions of RF entities and territorial and district election commissions. Supervision and control are of a strictly hierarchical character here and upper-level commissions can countermand every decision

36 In the successive campaigns ran: 1991 - 6 candidates, 1996 - 1, 2000 - 11, and in 2004, when another victory of V. Putin seemed certain - only 7 . When a real chance of the winning of somebody from outside the Kremlin appeared, the number of candidates was higher 9 in 1996, when B.Yeltsin's support was very a few months before the election and in 2000, when it was uncertain, how the voters would react to the candidature of the little-known prime minister, V. Putin), and when the result seemed a foregone conclusion, the number of candidates was markedly lower. This regularity recurred during the elections in March 2008, in which finally ran four candidates. 
of lower-level commissions, if they find them inconsistent with the law. Elections of the president of the Russian Federation, take place within a single electoral district encompassing the entire country, hence no district electoral committees are appointed.

Election commissions should operate openly. First of all, they are obligated to announce all decisions and information about the registered candidates, the election rules and results. In their sessions can participate as observers representatives of election commissions and candidates, and journalists. On the very voting day, the work of a commission can also be observed by representatives of international organisations, e.g., OSCE, the Council of Europe or organisations specialising in the protection of human and civil rights. These provisions of the constitutional law are consistent with the standards adopted in all stable democracies.

The rights and obligations of presidential candidates are defined by the law, so as to provide them with material conditions for competing with formally equal chances for victory. There are a number of such guarantees of equal opportunities:

1. Those candidates who perform functions in state or communal service, or in the mass media, are required to suspend their official activities during the election campaign, but they are entitled for monetary compensation due to the interruption in their professional activities for the time of the campaign. Only the incumbent president and the prime minister, if they are candidates, have the right to continue to perform their state functions and simultaneously participate in an election campaign. President B. Yeltsin in the elections of 1991 and 1996, as well as President V. Putin in both his campaigns of 2000 and 2004, obviously held their state offices during their election campaigns, in order to help their victory. This is a particularly delicate problem and it is known that no legal regulations, without the aid of critical media and ethical principles, good customs and fair competition rules will prevent the abuse of power by an incumbent leader in a struggle for a second term. This is not solely or chiefly a Russian peculiarity, but in Russia, particularly in B. Yeltsin's election for the second term, there occurred such gross abuses of fair play rules in this area, that the other candidates were 
not given equal opportunities, and especially candidates backed by the communist party ${ }^{37}$.

2. All of the above-mentioned persons, not excluding the incumbent president and the prime minister, should be careful not to abuse the privileges of their official positions during the period of electoral competition and in connection with their participation. The comments on the practice expressed in point 1 are even more pertinent here.

3. Each candidate, from the day of registration by their election commission, until the day of official announcement of the election results, has the right to use all means of transport free of charge (except taxis and special plane flights) during their travels over the territory of the Russian Federation, and the related costs are borne by the Central Election Commission which administers funds from the state budget or a credit which is repaid by the state budget after the elections. This rule is of great help indeed, in particular to less popular and influential candidates, because it helps them to promote themselves, their views or achievements, without having to bear the considerable costs of travelling. It is not many countries that use this transport privilege for presidential candidates, but with the meagre wealth of many candidates, it is, as experience has shown, of substantial practical significance.

4. A presidential candidate can have among their campaign helpers 200 trusted assistants who are allowed by the law to be on unpaid leave during the election campaign. Surely, this rule makes the operation of election committees easier and is intended to promote equal opportunities.

5. Candidates are allotted equal time of transmissions in television and radio programmes free of charge; this refers only to those programme broadcasters which are financed from the federal budget or from the budgets of federation entities. Private broadcasters do

37 There is a unanimous opinion on this matter among Russian researchers. It has been discussed by the authors of the most extensive studies of presidential elections in Russia. 
not have such restrictions and can, for a fee or free of charge, popularise those candidates who are supported by their owners.

6. Candidates take advantage of the substantial help of the state budget, which is to compensate for differences in the availability of private sources of financing for the campaign. It is important that means received from the Central election commission are allotted in equal amounts, irrespective of the probability of their actual chances of success. After registration, candidates establish a special election fund and open accounts in a specified national bank. They are allowed to accumulate the money only in those accounts, which, according to the law, may come from the following sources:

- the amount allotted by the Central Election Commission;

- the candidate's own funds, but not more than a thousand times the lowest salary from each of the donors;

- from the candidate's election committee (not more than fifty thousand times the lowest salary from a single donor);

- contributions from natural persons not more than fifty times the lowest salary from each of the donors;

- contributions from legal persons (not more than fifty thousand times the lowest salary from a single donor).

Apart from these restrictions, there is also a general limit of legally permitted expenditures on the campaign of each candidate: these expenditures may not exceed twenty-five times the minimum salary set by the federal act. The Russian law, similarly to election legislations of other countries, does not allow receiving funds from abroad or from companies operating in Russia, whose foreign capital exceeds 30\%. Anonymous contributions are not allowed, and if such should occur, they are taken over by the state treasury. In addition, Russian religious and military organisations, and local government organs are prohibited from providing financial support for any presidential candidate.

The infringement of these rules is punishable by sanctions: if a suspicion of breaching of these rules arises, the Central Election Commission is obligated to submit a request to revoke the registration of a candidate to the Supreme Court, which has five days to issue its opinion. 
For the course of the election struggle for presidency, of particular importance are the regulations on legal protection of persons and the reputation of the candidates. Each candidate enjoys special legal protection in the form of immunity, which means that they have a greater freedom of speech and behaviour in election competition than they would have under different circumstances. For any infringement of personal rights of their adversaries or other persons taking part in the election campaign, a presidential candidate may be punished; this can be done solely following the consent of the general prosecuting attorney of the Russian federation. There have been few such proceedings, which does not mean, however, that pre-election debates in Russia are moderate stylistically and non-aggressive with respect to their content.

Campaigning during elections and the manner of conducting it are regulated by law. These are specified: the duration of the campaign, institutional areas where no campaigning may be conducted for the candidates, and persons who, owing to their position in civil service, are prohibited from participation in election campaigning. The campaign period begins with registering a candidate (campaigning is forbidden beforehand, which is rarely obeyed by the committee and supporters of individual candidates) and ends, just as in many other countries, 24 hours before the day of voting. Also campaign silence has not been scrupulously respected by candidates.

There are basically two kinds of institutions in which the Russian law forbids election campaigning: firstly, state and local authority organs and armed forces institutions; secondly, the land and premises of religious organisations. Two categories of state officials are forbidden from taking part in election campaigning; these are members of election commissions and all persons holding positions in the state apparatus, but only during carrying out their duties. This regulation of election legislation has been one of the most often broken in hitherto presidential campaigns, since not only incumbent presidents, but also other candidates (e.g., the heads of regional administration or large military units) have tried to utilise all opportunities provided by their official positions during the competition. They have encouraged their subordinate civil servants and full-time advisors to doing that, and they rarely denied such help to their bosses. Indeed, 
complaints about such actions were submitted, but the sensitivity of Russian public opinion to such nuances of election procedures is not too high, and expectations are rather focused on the elementary precepts of integrity and fair play.

The law does not forbid clergy to participate in public life, but requires that religion be separated from struggles for power over the country and that priests do not use temples and their religious authority for political aims. In Russian reality, the Orthodox Church is usually pro-state and supports any authorities which are set up following elections, so these regulations are not particularly controversial within the society. Many candidates have tried in all their election campaigns to show their friendly attitude towards priests of minority denominations, such as Catholicism, Islam or Judaism.

The Russian election law differentiates between two kinds of defective presidential elections: an election which has failed to take place (nyesostoyavshyiesya), that is one in which have participated less than $50 \%$ of those registered as eligible voters, and a non-realistic (nyedyeistvityelnyie) election, that is one which does not make it possible for the Central Election Commission to determine the will of the voters due to numerous violations of the law. The Federation Council is obligated to announce a new election at very short notice. This norm has never had to be used, though there have been quite a lot of election law infringements in all hitherto presidential campaigns, which has been noted by OSCE observers and the Council of Europe, and numerous non-governmental organizations.

It is worth systematising the frequent and, in a way, typical breaches of the rules of equal and fair competition in the struggle for presidential power in Russia. Those were most often: manipulation of television and other media, abuse of official privileges, using more funds than permitted by the law, obtained from powerful financial groups in Russia. Both incumbent presidents took such actions in their struggle for re-election, but based on numerous and well-documented analyses, it can be observed that such strange events took place especially in 1996, when President Yeltsin, with the backing of the financial oligarchy, competed for a second term against the leader of the communist party, Gennady Zyuganov, and General Alexander Liebied. In the end, he won in the second round, by 
gaining $53.82 \%$ of the votes, whereas Zyuganov got $40.31 \%$ (over 300 million voters) and $4.82 \%$ people voted against both candidates. During that campaign, support of the voters was bought by President B. Yeltsin, who promised to particular groups of voters, for instance those employed in the army, the military industry or farmers, additional money or special legal regulations (e.g., he issued a decree permitting the purchase and sale of land, but the Duma found the decree unconstitutional). At his many meetings with the voters, he promised multi-billion subsidies for various sectors: educational, social, communal, cultural, which the federal budget mostly failed to deliver after the election. The persuasive effect of the president's promises in the campaign was significant and it definitely made it easier for him to defeat Zyuganov, who could not promise any extraordinary grants or subventions, or legal acts.

Each of the four campaigns had its peculiar characteristics. In two of the campaigns, it was obvious who would win, and victories occurred in the first rounds of voting: this way B. Yeltsin won his first term in 1991 and Putin his second in 2004. At that time, there were definitely less candidates (six and seven, respectively). There is a noticeable correlation between the uncertainty of the results (in 1996 and 2000) and the number of the candidates (up to eleven), which is a rational reaction.

The 2000 election was played out mainly with the use of military force in Chechnya, which established V. Putin as a staunch defender of territorial integrity of the Russian Federation and a guarantor of order in the whole country. No such means were used in the previous presidential campaigns. Both the choice of the moment for another pacification operation, as well as its scale, indicated the connection with the upcoming presidential election. Also at that time, there were numerous instances of repressions against the media and journalists who did not fully support or openly criticised the second war in Chechnya and the extent of repressions, bombings and destruction.

The drama of the struggle and the scale of breaches of the election law were at their highest when the result was difficult to predict, which also happens in many other countries. In the 2004 election, when it was clear that President V. Putin would easily win with more than $70 \%$ of the votes in the first round, strategists and the so-called political technicians were 
concerned with the voting frequency. It was feared that the attendance would not reach 50\%, making the election void, and it would have to be repeated. Attendance was high during the previous election, but a result known beforehand could dishearten the voters. The propaganda of $\mathrm{V}$. Putin's committee and some other candidates openly encouraged to participation, in order to avoid embarrassingly low attendance, frequent in post-communist countries. The fears failed to materialise, but the participation of the administration's officials in encouraging, or even forcing in some instances, was unquestionable ${ }^{38}$. The attendance was at $64.2 \%$ and President Putin got $71.31 \%$ of the votes cast. In some places, the attendance and support for V.Putin (e.g., Chechnya, Dagestan, Ingushetia) so greatly exceeded the average results that opinions appeared about fixing of the voting results in some of the districts.

To sum up, the election rules can be termed as indisputably democratic and consistent with the standards of stable democracies. The scale of infringement of these rules (in some periods insignificant, in others markedly greater) has never been said to be unacceptable by the majority of international observers - the recognition of the validity of an election has never been refused. Nonetheless, it is obvious that they were accompanied by informal manipulations and non-legal actions. At the same time, the citizens of the Russian Federation have elected their president five times now and none of them has abolished the fundamental rules. Despite the predictions of some analysts, even V. Putin did not do that. He did not use his enormous popularity to introduce changes in the constitution and remain in office for another term, although such a variant was suggested by observers of the Russian political scene, uncertain whether the successor would be able to maintain the ambitions and influences of the (sub) Kremlin political elites in a state of relative equilibrium.

Dmitry Furman (a Russian historian, aware of the distance separating present-day Russia from democracy) wrote about this decision that although it does not mean "chasing away all threats and the advent of democracy", it is important for the possibility of gradual shaping of

38 This is discussed, among others, by German journalist B. Reitschuster, Władimir Putin. Dokad prowadzi Rosje??, Warsaw 2005, p. 276 et seq. 
a democratic political culture - according to the assumption that "invoking democratic norms and values" alone "strengthens them to a degree" 39.

In general, democratisation theoreticians believe that a second election, free and fair, is an indication of consolidation of democracy. However, they do not apply this general criterion so eagerly to presidential elections in Russia, regarding democracy in this country as unconsolidated or even ostensible $^{40}$. Why is that? Many Russians believe that this means the use of double criteria of assessment by former sovietologists. Studious researchers of Russian politics could reply that beside the text of the constitution, the social and cultural context is of importance here, and without analysing the facts, the consequences of the accepted standards are not very clear.

\section{THE CONSTITUTIONAL PURVIEW OF PRESIDENTIAL AUTHORITY}

Presidential authority is usually classified in such a manner which shows what he can do as the head of state, and what as an organ oscillating, in a way, between his legislative and administrative-executive activities, as well as cooperating with the judiciary - with respecting the autonomy of the organs of each of the three types of state authorities. The typology of authority adopted here is traditional and based on institutional analyses referring to the principle of separation of powers.

Below is presented only the typology of acts of presidential authority (and not normative acts which constitute the foundations of law), to which he is entitled by the law, at the same time obligating him to taking specific decisions. This attempt at typology is needed, in order to avoid the rather

39 D. Furman, Russland am Scheideweg. Logik und Ende der "imitierten Demokratie", "Osteuropa" 2008, No. 2, pp. 3-15.

40 Cf. L. Diamond, Developing Democracy: Toward Consolidation, Baltimore 1999; J.J. Linz, A. Stepan, Problems of Democratic Transition and Consolidation: Southern Europe, South America, and Post-Communist Europe, Baltimore 1996; R.D. Anderson Jr., M.S. Fish, S.E. Hanson, P.G. Röder, Postcommunism and the Theory of Democracy, Princeton 2001. 
frequent in political science papers, hardly transparent presentation of the scope of presidential authority.

Authority, understood as powers combined with duties in a cohesive structure, can therefore be divided into four groups: 1) the authority of the head of state, 2) the authority over the nation and the representative/ legislative bodies of the Russian Federation; 3) the authority over the federal government; 4) the authority over the judiciary ${ }^{41}$.

1. The concept of the head of state is not used in many constitutions of countries which are stable democracies (e.g., France, the Federal Republic of Germany or the United States) ${ }^{42}$. The Russian constitution uses this term, but the legal doctrine does not feature a clear and more or less specified definition of the head of state ${ }^{43}$. Perhaps it is not required, since suggestions as to the understanding of this term are not discrepant and generally presume the head of state to be a personification of the entire country, its unity and identity, its sovereignty and independence. For the purpose of this analysis, in the first group of presidential authority are included: a) the role of the guarantor of the constitution, the state regime specified in it, and in particular civil rights and freedoms ${ }^{44}$; b)protection of state unity and integrality, by using arbitration procedures in contacting

41 This is a modified version of the typology presented in the book by E. Zielinski, System konstytucyjny Federacji Rosyjskiej, Warsaw 2005, p. 59. The author mentions only the powers, and not authorities; he does not take into account the authority of the president over the entities of the Federation (which is essential, because the Russian Federation is a federal state). Okunkov, quoted above, uses an intricate and abstruse typology of presidential authority, which discriminates: the role of the guarantor of the constitution, an entity using arbitration procedures, staffing powers, authority with regard to defence and state security, authority in the area of foreign policy. Other Russian authors follow a similar path; hence there is no relatively clear and comprehensive typology of the authority of the President of the Russian Federation.

42 This is indicated by N.A. Sakharov, Institut priezidientstwa $w$ sowriemiennom mirie, Moscow 1994.

43 Cf. S.A. Abalkin, Priezidient Rossiyskoy Fiedieraciy: evoluciya pravovogo statusa, "Wiestnik Moskovskogo Uniwiersitieta, Sieria 11: Prawo" 1998, No. 1; M.B. Agayev, Priezidientskaya vlast'v sistiemie gosudarstviennoy vlasti, Moscow 1994; V.I. Suvorov, Gwava Rossiyskogo gosudarstva, Moscow 2000.

44 W.E. Butler (op.cit., p. 88) aptly notes that "never before in Russian history has the constitution been placed above the monarch and the State". 
federation bodies, among others; c) representing the state within the country and abroad; d) specifying fundamental directions of domestic and foreign policy; e) the management of foreign policy of the state and, consequently, the acceptance of letters of credence and recall of diplomatic representatives of other countries and international organisations, and the appointment and recall of diplomatic representatives of the Russian Federation in other countries and international organisations; f) the role of the Supreme Commander-in-Chief of the Armed Forces, which entails the approval of the defensive doctrine of the Russian Federation and the appointment and dismissal of the highest-ranking military commanders, and additionally the shaping of the composition and management of the operation of the Security Council (Art. 83 of the constitution); g) the formation of the structure and appointments to presidential administration stipulated in the constitution as his organ. The role of the guarantor of the constitution (the second part of Art. 80) is generally understood as such coordination of state organs which prevents the endangering of the constitutional order, and the country can operate with cohesion sufficient to maintain its unity despite the distribution of duties and authority. Of particular importance is the combination of presidential authority in regard to the constitution with his role as the guarantor of civic rights and freedoms. Other aspects of his activities as the head of state will be subjected to more detailed analysis and confrontation with the practice in their respective chapters of the book.

2. The authority of the president towards the nation and the representative/legislative organ of the Russian Federation: a) supervision of the referendum and elections to the State Duma, a house of the parliament elected in general elections; $b$ ) dissolution of the Duma before the expiration of its tenure if the conditions specified in articles 111 and 117 of the constitution occur, that is when the Duma rejects a candidate for prime minister or passes the vote of no confidence for the government two times; c) leaving office under the conditions specified by the constitution of the Federation Council; d) participation in the institution of law by submitting bills, issuance of decrees and regulations in accordance with the constitution, signing and announcement of federal acts passed by the parliament; e) submitting to the Federal Assembly of annual addresses on the state of 
the country and the fundamental directions of domestic and foreign policy; f) authorisation of the draft government budget before sending it to the parliament. Presidential decrees are grouped in this typology in relation to legislative activity, because they enable the president to directly enter the law-making sphere, which is the essence of the parliament. Therefore, the president of the RF is also a legislative authority entity, and not only an executive one. The right to enact is important for the very reason that it defines the relations of the president of Russia with the parliament, and in particular with the Duma, differently to what has been done with the institution of the president in those countries where the separation of authorities in then organisational aspect has been conducted consistently - where the president has substantial executive authority, but he has no normative authority, no legislative initiative, and even more so, the right to issue decrees which could touch upon issues reserved for acts ${ }^{45}$.

3. The authority of the president pertaining to the judiciary at the federal level is as follows: a) presenting candidates for positions in the Constitutional Court, the Supreme Court and the Supreme Court of Arbitration to the Federation Council; b) submitting requests to the Constitutional Court regarding the investigation of compatibility with the constitution and explication of a bill. The president can, using his decrees or legislative initiatives, create new legal framework for the judiciary on all instance levels and within all types of organs. Irrespective of the frequent use of law as a tool in their power struggles, presidents have played major roles in the initiation and introduction of sweeping reforms in the judiciary, the public prosecution service and the police apparatus ${ }^{46}$. The conception of reforming the judiciary, prepared by a team headed by Boris

45 G. Prokofiev, D. Skuratov write in a similar vein on this issue in Probliemi kwassii kaciy form utshastia Priezidienta RF v pravovortsheskom prociessie, "Konstitucijyonnoye i Municyipalnoye Pravo" 2001, No. 3.

46 During B. Yeltsin's tenure, the main originators of the reforms were at first (19911993) legal scholars, aided by B. Yeltsin's legal advisors, and later (1994-1999), the initiative was taken by judges, confident of their new status. In 2001, President V. Putin personally initiated another stage of reforms prepared by his close collaborators, German Gref and Dmitry Kozak. See P.H. Solomon Jr., Putin's Judicial Reform: Making Judges Accountable as well as Independent, "East European Constitutional Review" 2002, Vol. 11, No. 1-2, passim. 
Zolotuhin, was approved in October 1991 by President Yeltsin and was the first programmatic document of post-Soviet Russia, realised with major consistency and at great financial cost. In May 2001, a team of Russian analysts under the supervision of Mikhail Krasnov evaluated the realisation of 160 reformatory initiatives from 10 years before, indicating that 95 of them had not been (fully) realised ${ }^{47}$. However, it is worth remembering that the juridisation of the judiciary brought about deep changes, such as the establishment of new types of courts (e.g., the Constitutional Court, the Supreme Court of Arbitration, courts with a jury for specific types of criminal cases), a new mode of appointing judges and the perpetual character of their function, introduced in order to ensure independence of judges, delegating to courts many decisions formerly lying in the hands of procurators, resignation from the institution of handing over cases to the prosecution service by courts for complementing evidence ${ }^{48}$. Key acts reforming the judiciary in Russia are the Judiciary Act of 1996, new penal and penal procedure codes, and the amendment of other acts, as well as a whole package of acts passed on the initiative of President V. Putin in 2001.

The scope of the authority described in the above typology is grounded in the constitution, in federal acts, as well as presidential decrees, because the Russian president has the right to enact certain norms of conduct for himself, provided that their compatibility with the constitution and federal acts is maintained. Below is a brief presentation of legal acts which the president can use in his legislative actions.

47 M. Krasnow, Is the "Concept of Judicial Reform" Timely? "East European Constitutional Review” 2002, Vol. 11, No. 1-2, www.law.nyu.edu/eecr/vol11num1_2/features/ krasnov.html. In the period 1995-1998, M. Krasnov was one of President Yeltsin's advisors supervising the introduction of judicial reforms.

48 A reliable analysis of the reforms of the Russian judiciary was presented by P.H. Solomon Jr., T.S. Foglesong, Courts and Transition in Russia: The Challenge of Judicial Reform, Boulder, Colorado 2001. 


\section{THE TYPES OF PRESIDENTIAL LEGAL ACTS}

The Russian system of legislative foundations is very complex, it encompasses over 40 names of normative acts, and their hierarchical order is not always respected by organs administering the law ${ }^{49}$. The Federal Assembly (a parliament consisting of two houses) is authorised to pass federal acts (zakon) and constitutional federal acts, the latter being passed with the same qualified majority as the constitution. The reason being that they are in reality amendments to the constitution or they regulate in more detail restricted matters, or ones already regulated in the constitution (e.g., the acts on the Constitutional Court, the Supreme Court and the Supreme Court of Arbitration used to be federal constitutional acts). Both kinds of acts can also be the results of a referendum.

Moreover, the parliament can issue resolutions (postanovleniye) ${ }^{50}$ on questions submitted to its authority, for instance, at the president's request, the Federation Council appoints in this manner the general prosecuting attorney, judges of the Constitutional Court, the Supreme Court and the Supreme Court of Arbitration. The State Duma pronounces amnesties in the postanovleniye mode (it does not fall under presidential authority) and appoints the president of the National Bank. Normative contents also contain such resolutions of the Federal Assembly as: polozeniye, kodieks, riegliament, osnova, obrashtsheniye, dieklaraciya, zayavlieniye and poslaniye. The government issues resolutions and regulations (postanovlenyie and rasporiazenyia) and the appropriate ministers issue such acts as: prikaz, instrukciya, ukazaniya and pravila ${ }^{51}$.

49 W.E. Butler, op.cit., p. 88.

50 Postanovleniye is often translated into English as decree, similarly to the presidential ukase, which might lead to misunderstandings; for this reason, postanovleniye will be translated here as act, ad not decree or regulation.

51 Russian terms have been used, in order to indicate the multitude of the names of sources of law as well as the ambiguity of many terms and the difficulty with determining their place in the hierarchy of Russian normative acts. Russian constitutionalists do not take a uniform stand on many issues; this pertains, e.g., to the question of whether a presidential decree is equally high in rank to a declaration or statement of the parliament. In order to avoid such disputes, the Russian parliament in general passes its dec- 
The president issues two kinds of legal acts: decrees (ukase) and regulations (rasporiazeniya). The constitution (Art. 90) does not specify for what matters one or the other form is more appropriate, but decrees are indisputably general normative acts, similar to bills, hence their correspondingly high place in the hierarchy of the fundaments of the Russian Federation law. Regulations are of a detailed character, they relate to specific natural persons (e.g., decorations) or legal persons (e.g., granting a subsidy to a particular school or community centre), or to internal organisation of the structures of the Administration of the President of the Russian Federation. Regulations are not normative acts, but administrative presidential acts. In general, there are no disputable problems on the doctrine regarding the proper matter for decrees and regulations of the president. But frequent there are opinions that the presidential administration alone is not consistent in the application of both forms of presidential decisions. Both are signed by the president in person and only under unusual circumstances he authorises the head of his office to use a facsimile. Both are published, with the exception of those which might contain state secrets ${ }^{52}$. There still exist exceptions to the principle of publication of legislation. The extent of secret law in the USSR was enormous: when in the wake of the reformatory ideas of perestroika began the disclosure of records which for years had been the secret law of the authorities, it could not be finished before the ultimate fall of the empire and the dissolution of the USSR in December 1991.

Disputes and problems arose at the meeting point of acts (zakon) and decrees (ukase). This was the result of drawing an unclear line between the legislative authority of the parliament and the president. After the dissolution of the parliament in October 1993, until December 1993 (until another election and the enactment of the constitution), presidential decrees were the only source of law. Before that time (since the autumn of 1991), B. Yeltsin, after the Supreme Council had given its consent,

larations, statements, etc. as federal acts and thus it gives them force equal to that of acts, which it does not do in the case of presidential decrees.

52 The preparatory mode of the acts of presidential authority was regulated by President Yeltsin's decree of 3 August 1996 (as amended). Cf. Por. M.V. Baglay, Konstituciyonnoye pravo Rossiyskoy Fiedieraciy, Moscow 1997, p. 413. 
became the head of the government and governed using decrees. It was then a period of factual primacy of the ukase over the act.

The problem with the presidential ukase caused mainly due the fact that the president can issue it in any matter, even one already regulated with a federal act. Decrees must not be contrary to acts, but they are not executive regulations with respect to acts, that is the president does not issue decrees in order to realise some particular acts and on the basis of a specific statutory authorisation. The president has general power to decree arising directly from the constitution (Art. 90, Item 1), just as the parliament to enact acts. The only limitation of this presidential power is the content of the decree, and not its subject. The content of the ukase may not infringe the constitution or federal acts, but it may touch upon statutory matter with it subject; essentially, decrees of the president of Russia have the power of acts, though they are not termed this way in the constitution.

Presidential decrees are fundamentally exempt from approval by the parliament; they are valid directly on the territory of the entire Russian Federation and come into effect according to the president's will, which cannot be later changed with the parliament's decision ${ }^{53}$. In the 1978 constitution of the Russian Soviet Federative Socialist Republic, decrees were not subject to approval and could be modified by the parliament. Under the rule of the 1993 constitution, only the president can repeal his decrees, as did President Yeltsin with some of his decrees from the autumn of 1993, when the parliament was dissolved ${ }^{54}$.

53 In under 10 weeks, B. Yeltsin and his administration produced more than 230 pages of decrees, which was reported, e.g., by Okunkov, Priezidient Rossiiskoi Fiedieracii, op.cit., p. 88.

54 Critics of the style and policy of Boris Yeltsin argued that the president's propensity for governing with decrees was a manifestation of his fondness of tsarist absolutism and authoritarian traits. O.G. Rumiantsev, Vienok dlia vłastoliubtsa: Boris Yeltsin i gibiel diemokratii v Rossii, 1998, www.rumiantsev.ru. From the spring of 1990 to the dissolution of the Duma by B. Yeltsin in September 1993, Oleg Rumiantsev was, at B. Yeltsin's invitation, Secretary General of the Constitutional Commission. The first draft of the Commission was ready as early as September 1990; it was printed in 36 million copies, in order to conduct extensive consultations. The Commission was headed by the trio: 
There exists, however, one exception to the presidential decree independence rule: only decrees introducing martial law or a state of emergency (Art. 102 of the constitution) require approval and only by the Federation Council. The Federation Council in this case is not so much part of the legislative parliamentary authority, as a representative of all entities of the Russian Federation and it expresses its opinion for the particular purpose of making it clear that the entities of the Federation are bound by a presidential decree on an extraordinary issue. This approval results from the principle of federalism and is not devised as a legal limitation of the president's power which is manifested through decrees. Decrees are therefore normative acts of presidential power, they have a general foundation in the constitution and are independent, do not require approval by the parliament or a countersignature of the prime minister or a minister ${ }^{55}$.

The independence of the decree elevates its power and significance as an instrument of authority. The president of the United States does not have such a means of governance at his disposal. In France, the president has the right to issue decrees, but their power does not equal that of acts. The reference to the French model by the Russian 1993 constitution is undisputable; however, it does not mean full reception of the French model. In this respect, the president of the $5^{\text {th }}$ French Republic appears to be weaker than the president of the Russian Federation, but such a view would not be an accurate opinion. The French constitution gives the president almost full control over the composition and policy of the government, and the government is equipped with grater legislative power than the parliament. As a result, the president of France, acting through

Boris Yeltsin, Ruslan Khasbulatov (the then president of the parliament) and Oleg Rumiantsev.

55 Due to the lack of consistency in the use of decrees by the president, some constitutionalists have been right to point out that certain decrees do not possess a normative character, but are individual, specific administrative, not legislative, acts. See W.E. Tshirkin, Komientarii do art. 80-93, [in:] Konstituciia Rossiiskoy Fiedieracii: nautshno-prakticzeskii komientarii, B.N. Topornin (ed.), Moscow 1997, p. 505. This state of affairs is not, however, synonymous with the intent of the legislator for decrees to also be nonnormative or, as the papers said about some decrees of Yeltsin, "lobbing-related". 
the government, has more legislative power than the president of Russia, if he does not have a majority in the Duma (this was the case during both terms of B. Yeltsin and the first term of V. Putin). Accordingly, without examining the actual power structure, it cannot be assumed that the Russian president has more legislative power, thanks to his decrees, than the president of France. Only when President V. Putin built a majority coalition around the United Russia (Yedinayia Rossia) party during his second term, did his position as a legislator become as strong as that of the president of France. This is not because of decrees, which President Putin did not abuse like his predecessor, but because of the presence of the presidential party in the parliament. In the Russian constitutional regime, for a president who does not have a majority in the Duma, the decree with the power of the act is a very convenient substitute of political power in the parliament. The decree is therefore an 'umbrella for bad weather', for the lack of support of a parliamentary majority; it is an important instrument for Russian presidents, because cohabitation in the Russian milieu is usually tantamount to more severe confrontation than in France.

On several matters, the president of the $5^{\text {th }}$ French Republic is institutionally stronger than the president of Russia. The right to dissolve the parliament before the end of its term is broader in France than in Russia: in France, the president may, upon consultation with the prime minister and the chairs of both houses of the parliament, dissolve the National Assembly at any moment and for any reason which he deems valid. The president of Russia, however, can dissolve the parliament only in two situations and both pertain to a conflict with a majority in the parliament on the appointment of the prime minister or a vote of no confidence for the government ${ }^{56}$. The Russian constitution is not designed to make it

56 There are two more aspects in which the President of the $5^{\text {th }}$ Republic is more powerful institutionally, that is extraordinary powers for the president and the appointment of judges to the Constitutional Council. In both respects, the president of the Russian Federation has less extensive powers than his French counterpart. He may not (upon consultation with the prime minister, whom he also picks himself) grant himself additional, extraordinary authority which is not present in the constitution and other acts in force, on the other hand, the president of France can do so. The French president can is authorised to appoint one-third of the members of the Constitutional Council, 
easier for the president to end the parliament's term earlier. Quite to the contrary, this is limited to two instances of inability of the president and the parliament to cooperate: when the parliament rejects the president's candidate for the office of prime minister three times or when it gives the government a vote of no confidence two times. Then, the president of Russia may dissolve the parliament and he must call another election. This restriction of the right to dissolve the parliament is clear and its definition results from practical experiences of President Yeltsin in the period 1991-1993. It is therefore not an abstract idea of the designers of the constitution or an intellection of political technologists guided by an expedient calculation. Harsh experiences brought conclusions which the creators of the constitution took into consideration.

Decrees have a long and non-democratic tradition in the history of regimes and the history of law. They are unipersonal acts, in a way arbitrary and not requiring voting or compromises. The decree is thus an ideal instrument of authoritarian government and it needs to be carefully monitored how, by whom and to what ends it is used. In Russia, decrees used to be employed for top-down reforms ${ }^{57}$ or by revolutionary authorities elected on a bottom-up basis. Tsar Peter I the Great issued more than

whereas the president of Russia may not appoint by himself any judges of the Constitutional Court. The president of Russia participates in a convoluted procedure of appointing judges involving multiple factors. Firstly, he is given suggestions by many institutions, such as deputies, senators, legislative authority organs of Federation entities, the highest court organs and federal legal protection agencies, lawyers' associations and legal scientific institutions. During the second stage, he chooses and submits some of those suggestions as his own appointment recommendations and the Federation Council selects from among them and appoints judges to the Constitutional Court. Obviously, the path to such a nomination in Russia is more complex than in France. President Yeltsin was in fierce conflict with the Constitutional Court which was suspended in September 1993. The court resumed with a new bench and with a new chair only in February 1995; the new Constitutional Court Act of 1994, on the basis of the 1993 constitution, limited some powers of the court, but the procedure of appointing its members remained unchanged. For French presidency, cf. D.S. Bell, Presidential Power in Fifth Republic: France, Oxford 2000.

57 Peter I the Great modernised Russia with his decrees and in 1711 he also granted to the Senate the right to issue decrees on his behalf in his absence. Cf. the classic case of N.M. Korkunov, Ukaz i zakon, Saint Petersburg, 1894. 
3000 legal acts during his rule, mostly decrees. Bolsheviks were using government decrees when they were laying the foundations for a new regime (land and peace decrees were the first acts of the new authorities). Boris Yeltsin, when he was the president of Russia, both before the December constitution, as well as after its passage, similarly used decrees as a ram breaking the Soviet system (after the failed coup in August 1991, Yeltsin used decrees to delegalise the CPSU, seized its assets with the Russian state treasury and abolished the 1978 constitution), then as an instrument building the foundations for a new system of ownership (decrees were used for the introduction of privatisation and in market economy institutions). And surely the revolutionary purposefulness, both in 1917, as well as in 1991 and a year later, was more important than formal legalism, perfection of legislative texts or their coherence ${ }^{58}$.

President Yeltsin issued over 10,000 decrees, several times the amount of acts passed during that time, although the Russian parliament was very dynamic throughout those ten years. The president often forestalled acts on which the Duma was working, in order to regulate some matter differently. A decree was usually faster than an act, usually it also introduced more of substantial changes in a shorter time than acts, which were slow to develop and based on numerous compromises. Not only because the president was radical and the parliament moderate or conservative. Also because standards are invented differently in the cabinets of presidential advisors than in complicated procedures of the workings of parliamentary commissions and clubs, especially if parties are too immature and discipline and loyalty of the members towards their parties are low.

\footnotetext{
58 Sharp criticism of Yeltsin's decree authority from the standpoint of defence of the Soviet constitutional order is presented by the publication of Vladimir Lutshin, a former judge of the Constitutional Court, "Ukaznoye pravo" v Rossii, Moscow 1996. A substantive analysis of Yeltsin's decrees from a legal-comparative perspective is provided in the monograph by V.O. Lutshin, A.V. Mazurov, Ukazy Priezidienta: osnovniye sociialniye i pravovye haraktieristiki, Moscow 2000.
} 


\section{NORMATIVE LIMITS OF PRESIDENTIAL AUTHORITY}

All of the powers presented above had their normative limitations and none gave the president unlimited power. Several kinds of normative limits of presidential authority can be distinguished: legal and non-legal, and among the latter, cultural norms associated with the voters' expectations of the leader elected in general elections, ethical norms regarding honesty and the sense of duty, standards relating to the criteria of political correctness, formed by public opinion in Russia and outside of its borders.

The legal limits of presidential authority are:

1. The content of the constitution and other federal acts defining presidential authority (which has been analysed in points $1-3$ of this chapter).

2. The content of the constitution and other federal acts which grant exclusive authority to other principal organs of the state, and foremost to the parliament, the government and courts (e.g., the requirement of a parliamentary act approving the state budget, numerous legislative initiatives of deputies and the resulting acts, the right to pass a vote of no confidence for the government). A vote of no confidence for the government does not mean the necessity of dismissing it, because the government does not have to answer politically and constitutionally to the parliament. A vote of no confidence passed once is a warning for the prime minister and the president, but passed a second time becomes a risk to the parliament itself; the president can then dissolve the parliament, which will result in a new election. A vote of no confidence passed by the parliament and the right to dissolve the parliament by the president are at odds here and impose constraints on each other - the parliament and the president are met with limitations in the form of legal standards and it is dependent on non-legal standards who restricts whose field of activity more. Generally, it can be said that the parliament's capacity to control the president is very modest.

3. Constitutional means of execution of the president's responsibility for high treason or other grave crimes. The constitution of the Rus- 
sian Federation does not provide for constitutional responsibility or the responsibility for infringement of the law, and bringing about the deprivation of the president of his office is very difficult. It requires very competent and quite harmonious cooperation of the three principal state organs: the Supreme Court, the Constitutional Court and both houses of the parliament. The very notion of high treason (which, beside a grave crime, is the only action permitting the instigation of proceedings to remove the president from office) is legally underspecified; when the constitution was being passed in December 1993, the Russian criminal law did not include the notion of such a crime. In order for the Duma to be able to impeach the president and petition the Federation Council to depose him, there are required: a prior ruling of the Supreme Court that the president has committed a crime; additionally, a ruling of the Constitutional Court that the procedure of making an accusation is lawful. A special commission appointed by the duma on the initiative of at least one-third of the members of this house submits a request to indict the president. If the Duma passes the motion with a qualified majority of two-thirds of the total number of deputies, it is referred to the Federation Council, which can pass it and deprive the president of office, for which there is also required a qualified majority of two-thirds of the total number of its members. One can hardly imagine a more complicated procedure. The lawyers working for Yeltsin after the 'court martialling of the parliament' and before the constitutional referendum in December 1993 made the president's position unimpeachable. Presidential immunity guaranteed by the constitution is an absolute privilege, with no exceptions or constraints. 